\title{
Pengembangan Paket Pelatihan "Ground, Understand, Revise, Use (Guru)-Karier” untuk Meningkatkan Efikasi Diri Karier Calon Konselor
}

\author{
Nora Yuniar Setyaputri ${ }^{1}$, Blasius Boli Lasan ${ }^{2}$, Devi Permatasari ${ }^{3}$ \\ ${ }^{1}$ Prodi Bimbingan dan Konseling-Fakultas Keguruan dan Ilmu Pendidikan- \\ Universitas Nusantara PGRI Kediri-Jl. K.H. Ahmad Dahlan No. 76, Kediri, Jawa Timur 64112 \\ ${ }^{2}$ Jurusan Bimbingan dan Konseling-Fakultas Ilmu Pendidikan-Universitas Negeri Malang- \\ Jl.Semarang No. 5, Malang, Jawa Timur 65145 \\ ${ }^{3}$ Prodi Bimbingan dan Konseling-Fakultas Ilmu Pendidikan-Universitas Kanjuruhan Malang- \\ Jl. S. Supriadi No.48, Kota Malang, Jawa Timur 65148 \\ E-mail: setyaputrinora@gmail.com
}

Artikel diterima: 6 Oktober 2016; direvisi 4 November 2016; disetujui: 4 November 2016

\begin{abstract}
Abstrak: Bimbingan dan Konseling merupakan suatu sistem, yaitu meliputi: masalah, tujuan, teknik, media dan evaluasi. Suatu teknik dalam pelaksanaan layanan BK tidak dapat berdiri sendiri oleh karena itu perlu diwadahi oleh suatu media. Fungsi dari media bimbingan dan konseling adalah untuk memperlancar proses pelaksanan layanan BK tersebut. Teknik yang dipilih adalah Proses GURU (Ground, Understand, Revise, Use) sedangkan media yang dipilih adalah paket pelatihan "GURU-Karier". Tujuan penelitian ini yaitu untuk menghasilkan media bimbingan dan konseling berupa Paket Pelatihan "GURU-Karier" yang dapat diterima secara teoretis dan praktis. Penelitian ini menggunakan metode penelitian dan pengembangan. Model pengembangan yang digunakan adalah model penelitian dan pengembangan Borg \& Gall 1983. Paket pelatihan ini terdiri dari 2 eksemplar, yaitu 1) paket pelatihan untuk pegangan konselor dan 2) paket pelatihan untuk pegangan konseli. Berdasarkan hasil uji ahli BK, uji ahli pengembangan media pendidikan, uji pengguna dan uji kelompok kecil pada 6 mahasiswa BK (calon konselor) dapat disimpulkan bahwa paket pelatihan "GURU-Karier" terbukti layak diterima sebagai media bimbingan dan konseling untuk meningkatkan efikasi diri karier calon konselor. Saran yang diajukan dalam penelitian ini antara lain agar para dosen BK dan guru BK/konselor dapat menggunakan paket pelatihan "GURU-Karier" untuk meningkatkan efikasi diri karier calon konselor, dapat menggunakan paket pelatihan ini sebagai sarana pengembangan pribadi konselor, bagi peneliti selanjutnya dapat menggunakan subjek penelitian yang lebih luas, mengganti rancangan penelitian menjadi penelitian eksperimental dengan kelompok kontrol serta penelitian tindakan bimbingan dan konseling.
\end{abstract}

Kata kunci: paket pelatihan "GURU-karier"; efikasi diri karier; calon konselor

Bimbingan dan Konseling merupakan suatu sistem yang di dalamnya terdapat beberapa komponen yang saling berkaitan satu sama lain. Komponen-komponen tersebut meliputi: masalah, tujuan, teknik, media dan evaluasi (Nursalim, 2013). Agar tujuan dalam pemberian layanan BK baik di sekolah maupun di luar sekolah dapat tercapai, komponen-komponen tersebut harus dipenuhi oleh konselor. Seperti penggunaan media dalam pemberian layanan BK merupakan suatu hal yang sangat dianjurkan. Pesan bimbingan dan konseling dapat tersampaikan dengan baik atau tidak bergantung pada media yang terdapat pada proses tersebut (Setyaputri dkk, 2015). Media BK 
merupakan sarana yang dapat memperlancar proses pelaksanaan layanan Bimbingan dan Konseling dan dapat membantu guru BK/Konselor dalam penyampaian materi bimbingan (Leksana dkk, 2013).

Keefektifan dari penggunaan media BK telah dibuktikan oleh beberapa penelitian seperti penelitian Anisa dan Nursalim (2010) yang berjudul Efektivitas Media "Pizza Karier" dalam Pemberian Layanan Informasi Karier, hasil penelitian ini membuktikan bahwa dengan menggunakan media pizza karier dapat meningkatkan pemahaman siswa mengenai materi yang disampaikan. Penelitian Leksana dkk (2013) yang berjudul Pengembangan Modul Bimbingan Karir Berbasis Mulitimedia Interaktif untuk Meningkatkan Kematangan Karir Siswa, penelitian ini membuktikan bahwa dengan menggunakan modul bimbingan karier berbasis multimedia interaktif dapat meningkatkan kematangan karier siswa. Penelitian Elfarini dan Christiana (2013) yang berjudul Pengembangan Media Monopoli Asertif untuk Meningkatkan Pemahaman Siswa tentang Perilaku Asertif pada Siswa Kelas VIII-A, membuktikan bahwa dengan menggunakan media monopoli asertif dapat meningkatkan pemahaman siswa tentang perilaku asertif. Penelitian Setyaputri dkk (2015) yang berjudul Pengembangan Media Permainan "Roda Pelangi" untuk Meningkatkan Efikasi Diri Siswa SMP dalam Menghadapi Ujian, membuktikan bahwa dengan dikembangkannya media permainan Roda Pelangi dapat meningkatkan efikasi diri siswa SMP dalam menghadapi ujian.

Hasil-hasil penelitian di atas merupakan beberapa bukti teoretis dan praktis bahwa media memiliki peran penting untuk membantu pelaksanaan layanan BK. Peran yang dimaksud adalah membantu konseli agar dapat berkembang secara optimal. Salah satu dimensi yang tidak kalah penting agar konseli dapat berkembang secara optimal adalah pemberian layanan untuk membantu konseli agar dapat mandiri dalam mengambil keputusan. Pengambilan keputusan ini mencakup segala hal dalam hidup konseli, baik mengenai pemilihan sekolah lanjutan maupun pekerjaan apa yang nanti akan dipilih. Hal ini berkaitan dengan pengambilan keputusan karier konseli.

Salah satu variabel yang berhubungan dengan pengambilan keputusan karier seseorang adalah efikasi diri. Pernyataan ini didukung oleh pendapat beberapa ahli yang menyatakan bahwa efikasi diri mempunyai pengaruh yang signifikan terhadap pengambilan keputusan karier individu (Bandura dkk, 2001; Betz, 2007; Bozgeyikli dkk, 2009; Hackett dalam Bandura, 2009). Efikasi diri yang berkaitan dengan bidang karier seseorang dapat disebut sebagai efikasi diri karier. Efikasi diri karier adalah keyakinan individu pada kemampuan dirinya untuk melakukan aksi terkait dengan aktivitasnya hingga mendapatkan sebuah keberhasilan dalam bidang karier (Feehan \& Johnston, 1999; Anderson \& Betz, Lenz \& Hackett (dalam Brusokas \& Malinauskas, 2014)).

Menurut Betz (2007), Gibson \& Mitchell (2008) dan Brusokas \& Malinauskas (2014), ada 4 faktor yang dapat memengaruhi tingkat efikasi diri karier seseorang yaitu: (1) pengalaman belajar/ pengalaman menguasai sesuatu (experience of mastery); (2) pengamatan terhadap orang lain atau modeling sosial (vicarious experience); (3) persuasi sosial (social persuation); dan (4) kondisi emosional positif dan negatif (positive and negative emotional state). Pengalaman belajar/ pengalaman menguasai sesuatu (experience of mastery) merupakan interpretasi individu terhadap keberhasilan yang dicapai individu pada masa lalu. Pengamatan terhadap orang lain (vicarious experience) merupakan proses modeling atau belajar dari orang lain. Efikasi diri individu akan meningkat apabila dipengaruhi model yang relevan. Pengalaman orang lain menentukan persepsi akan keberhasilan atau kegagalan individu. Persuasi sosial (social persuasion) merupakan persuasi yang dilakukan oleh orang-orang yang menjadi panutan dan memiliki kemampuan untuk mewujudkan hal tersebut. Kondisi emosional positif dan negatif (positive and negative emotional state) berkaitan dengan penilaian individu dalam menilai kemampuan, kekuatan dan kelemahan dirinya.

Keberadaan efikasi diri karier penting untuk dimiliki dan ditingkatkan pada diri seseorang karena mempunyai beberapa fungsi penting untuk keberhasilan karier mereka. Dapat disimpulkan dari pendapat Schunk (1991), Bandura (1993; 1994; 1998), Gushu, dkk (2006), Brusokas \& Malinauskas (2014) beberapa fungsi penting tersebut antara lain: (1) individu yang mempunyai efikasi diri karier yang tinggi akan lebih berusaha keras untuk mendapatkan pekerjaan yang diinginkan; (2) seseorang akan lebih giat untuk meningkatkan prestasi kerjanya; (3) dapat mengatur 
diri untuk sebuah tujuan yang menantang dan mempertahankan komitmennya dalam mewujudkan hal yang berkaitan dengan kariernya; (4) dapat meningkatkan dan mempertahankan usahanya dalam menghadapi kegagalan yang berkaitan dengan profesi yang ditekuni; (5) individu tersebut dengan cepat memulihkan kembali semangat pada dirinya setelah mengalami kegagalan; (6) dapat mereduksi stres dan depresi yang akan terjadi pada dirinya; (7) seseorang yang memiliki efikasi diri karier tinggi cenderung lebih menetapkan tujuan karier yang lebih tinggi pula dan lebih tekun dalam mencapai tujuannya tersebut.

Apabila tingkat efikasi diri karier pada konseli rendah maka hal-hal yang berkebalikan dengan fungsi di atas akan terjadi. Rendahnya efikasi diri karier konseli tersebut biasanya berkaitan dengan adanya kebimbangan mengenai pemilihan studi lanjut, jenis pekerjaan atau profesi yang hendak ditekuni, informasi tentang kelompok kerja yang akan dipilih, tidak adanya dukungan dari orang tua dan teman sebayanya, faktor ekonomi yang tidak mendukung atau mereka sebenarnya belum memahami potensi diri mereka sendiri serta cenderung pasrah dengan keadaan.

Permasalahan ini tidak hanya terjadi pada siswa atau pelajar yang sedang duduk di bangku sekolah menengah saja. Hal ini tetap ada bahkan dapat berlanjut sampai pelajar tersebut duduk di bangku kuliah (mahasiswa). Akan tampak sangat ironis apabila yang memiliki keyakinan diri yang rendah terhadap profesi yang akan ditekuninya nanti adalah mahasiswa jurusan S1 Bimbingan dan Konseling. Dimana nantinya mereka diharapkan dapat menjadi guru BK/konselor yang kompeten di bidangnya.

Mengacu pada pemaparan di atas dapat diketahui bahwa efikasi diri karier sangat penting untuk dimiliki konseli, khususnya mahasiswa S1 BK. Berdasarkan hasil studi pendahuluan yang dilakukan oleh peneliti melalui proses wawancara kepada mahasiswa semester 7 tahun ajaran 2015/2016 Program Studi S1 BK Universitas Nusantara PGRI Kediri, ditemukan efikasi diri karier yang masih rendah pada diri calon konselor tersebut. Dari masing-masing kelas ditemukan kurang dari 10 mahasiswa yang mantap menjadi guru BK/ konselor, sedangkan jumlah maksimal mahasiswa dalam satu kelas berkisar antara 30-45 orang. Kurangnya efikasi diri karier yang terjadi pada calon konselor ini ditandai dengan adanya kebimbangan mereka berkaitan dengan kejelasan profesi mereka, akan studi lanjut ataukah bekerja, mereka kurang yakin mampu menjadi konselor yang profesional, kurang yakin dapat menyesuaikan diri dengan iklim sekolah, keinginan diri yang tidak sesuai dengan kehendak orang tua, serta ketersediaan lapangan pekerjaan bagi mereka.

Permasalahan ini perlu dikritisi oleh para pengajar calon konselor tersebut. Jika mereka yang nantinya diharapkan dapat menjadi konselor yang profesional ternyata masih mempunyai efikasi diri karier yang rendah terhadap profesinya, dikhawatirkan hal ini akan berpengaruh pada kinerja mereka di sekolah maupun di luar sekolah. Perlu dilakukan upaya tersendiri untuk menyelesaikan permasalahan ini. Selain itu, upaya tersebut dapat digunakan untuk mendukung tugas konselor di jenjang perguruan tinggi. Pemaparan ini didukung oleh pendapat Santoso (2011) yang menyatakan bahwa di jenjang perguruan tinggi pelayanan bimbingan dan konseling lebih difokuskan pada pemantapan karier, sebisa mungkin yang paling cocok baik dengan rekam jejak pendidikannya maupun kebutuhan untuk mengaktualisasikan dirinya sebagai pribadi yang produktif, sejahtera serta berguna untuk manusia lain.

Mengingat betapa pentingnya penggunaan media BK sebaiknya dalam pemberian layanan untuk meningkatkan efikasi diri karier tersebut, konselor dapat secara kreatif memilih serta menggunakan bahkan mengembangkan media tertentu disesuaikan dengan sasaran dan materi layanan yang akan diberikan kepada konseli. Salah satu jenis media BK yang dapat digunakan untuk pemberian layanan mengenai efikasi diri karier adalah paket pelatihan. Paket pelatihan dipilih karena salah satu faktor yang paling berpengaruh pada efikasi diri karier adalah pengalaman. Dimana untuk menciptakan sebuah pengalaman perlu dilakukan sebuah praktik melalui pelatihan.

Beralih pada komponen lain yang tidak kalah penting dalam sistem BK adalah teknik. Telah diulas sebelumnya bahwa hal yang paling dominan dalam efikasi diri karier adalah pengalaman, maka teknik yang dipilih adalah Proses GURU. GURU adalah akronim dari Ground, Understand, Revise dan Use. Proses GURU merupakan salah satu bentuk praktik reflektif dimana praktik reflektif ini berkaitan erat dengan konsep experiential learning. Praktik reflektif dan experiential 
learning mempunyai satu kesamaan yaitu dalam proses pelaksanaannya mengutamakan pengalaman apa yang telah dialami individu dan merefleksikan hal tersebut untuk memperoleh tindakan yang lebih efektif dan produktif (Silberman, 2007).

Menurut Remer (2007) GURU adalah perangkat yang amat luwes. Maksudnya, dengan menggunakan proses GURU, konselor dapat menciptakan suatu proses bimbingan yang berkesinambungan dengan memanfaatkan pertanyaan-pertanyaan yang dapat menggali dan mengubah pola pikir calon konselor mengenai efikasi diri karier mereka. Selain itu kondisi lapangan mayoritas memerlukan teknik-teknik yang praktis, mudah diaplikasikan serta memiliki tahapan yang tidak terlalu panjang. Proses GURU dilakukan dengan tahap yang dioperasionalkan mengikuti akronimnya yaitu: Ground, Understand, Revise dan Use.

Ground (dasar/pondasi) merupakan tahap dimana seseorang diberikan pertanyaan-pertanyaan mendasar mengenai pengalaman yang telah dialami. Hasilnya adalah informasi yang dinamakan dengan data dasar yang memuat tentang pemahaman, pengetahuan atau pengalaman calon konselor yang berkaitan dengan efikasi diri kariernya. Understand atau tahap pemahaman bertujuan agar seseorang mendapatkan pemahaman yang lebih luas dan lebih mendalam terkait topik yang dipelajari. Hasilnya adalah diperolehnya pemahaman baru yang lebih luas serta mendalam dibandingkan dengan pengalamannya yang terpaparkan dalam data dasar. Khususnya yang berkaitan dengan pengalaman kognitif maupun emosional yang berkaitan dengan efikasi diri karier calon konselor.

Selanjutnya adalah Revise (revisi). Tahap revisi ini merupakan tahap yang memungkinkan seseorang untuk memperbaiki pikiran dan aspek emosionalnya menjadi lebih baik. Jadi, hasil dari tahap ini adalah pemahaman atau pengalaman kognitif dan emosional yang lebih baik dan efektif untuk diaplikasikan pada kehidupan selanjutnya dalam rangka mencapai tujuan. Use atau tahap penggunaan merupakan tahap dirumuskanya rencana tindakan yang operasional, rinci dan lebih riil dimana memungkinkan konseli untuk mengaplikasikanya dengan lebih mudah dan bertanggung jawab. Hasil mengenai tindakan yang operasional ini dapat dilihat melalui praktik simulasi yang menjadi bagian dari pelatihan yang tercover dalam paket pelatihan tersebut.

Adapun kaitan proses GURU dengan bidang karier telah dibuktikan oleh penelitian Hanggara (2016) yang berjudul Keefektifan "Proses GURU” sebagai Teknik Bimbingan Kelompok dalam Meningkatkan Kemampuan Pengambilan Keputusan Karier Siswa SMK. Hasil penelitian ini membuktikan bahwa dengan menggunakan proses GURU kemampuan pengambilan keputusan karier siswa SMK dapat ditingkatkan. Telah diulas sebelumnya bahwa kemampuan pengambilan keputusan karier ini erat hubungannya dengan efikasi diri karier individu. Maka, dengan hasil penelitian tersebut memperkuat bahwa proses GURU dapat digunakan untuk meningkatkan efikasi diri karier calon konselor.

Berdasarkan adanya homogenitas yang ada dalam kelompok, maka strategi yang dipilih adalah bimbingan kelompok. Ciri homogenitas ini yang ikut menandai layanan bimbingan kelompok dan membedakannya dari konseling kelompok (Prayitno \& Amti, 2009). Sedangkan DeLucia-Waack (2006) menyatakan bahwa bimbingan kelompok memiliki peran yang sifatnya lebih pada pencegahan terjadinya suatu permasalahan dalam diri individu. Jadi, dengan menggunakan strategi layanan berupa bimbingan kelompok, pengubahan pola pikir calon konselor yang berkaitan dengan rendahnya efikasi diri karier serta pembentukan tingkah laku baru dapat dikembangkan.

Disimpulkan dari pendapat Brown (2004), DeLucia-Waack (2006), dan Corey dkk (2014) bahwa jumlah anggota yang ideal dalam satu kelompok jika anggotanya berusia lebih dari 9 tahun adalah 5-8 orang. Durasi dalam satu sesi bimbingan jika usia masing-masing anggota dalam satu kelompok lebih dari 9 tahun adalah 40-70 menit (Gazda, Thompson \& Rudolph (dalam DeLuciaWaack, 2006)). Tahapan bimbingan kelompok yang digunakan adalah tahapan bimbingan kelompok dari Corey, dkk (2014), yang terdiri dari 5 tahap yaitu: 1) pre-group (tahap pembentukan kelompok); 2) initial stage (tahap awal); 3) transition stage (tahap transisi); 4) working stage (tahap kerja); dan 5) final stage (tahap akhir). Keempat tahapan Proses GURU dilaksanakan pada tahap kerja (working stage). 
136 | Jurnal Kajian Bimbingan dan Konseling Vol. 1, No. 4, 2016, hlm.132-141

\section{Tabel 1. Rincian Kegiatan dan Jabaran Materi Pelatihan}

\begin{tabular}{|c|c|c|c|}
\hline Pertemuan & Tahap & Waktu & Deskripsi Kegiatan dan Materi \\
\hline & Pre-Group & & $\begin{array}{l}\text { Persiapan pelaksanaan pelatihan dan seleksi anggota } \\
\text { melalui Skala Pengukuran Efikasi Diri Karier yang } \\
\text { telah valid dan reliabel (pretest). }\end{array}$ \\
\hline \multirow[t]{3}{*}{ Pertemuan 1} & Initial Stage & 40 menit & $\begin{array}{l}\text { Pemimpin kelompok memaparkan gambaran kegiatan } \\
\text { yang akan dilakukan. Selanjutnya anggota kelompok } \\
\text { diajak untuk saling mengenal dan akrab satu sama lain } \\
\text { agar terjadi kenyamanan, kohesifitas dan saling } \\
\text { menerima. }\end{array}$ \\
\hline & $\begin{array}{l}\text { Transition } \\
\text { Stage }\end{array}$ & 20 menit & $\begin{array}{l}\text { Pemimpin kelompok mengajak para anggota kelompok } \\
\text { untuk menyesuaikan diri dengan tahap selanjutnya. } \\
\text { Pemimpin kelompok juga menjelaskan sikap, peran } \\
\text { dan tugas masing-masing secara jelas baik pemimpin } \\
\text { kelompok sendiri maupun anggota kelompok sehingga } \\
\text { menjadi lebih jelas dan yakin dengan apa yang akan } \\
\text { dilakukan selama kegiatan kelompok. }\end{array}$ \\
\hline & \multicolumn{3}{|c|}{ Working Stage (pertemuan 2-8) } \\
\hline Pertemuan 2 & $\begin{array}{l}\text { Pelaksanaan } \\
\text { tahap Ground }\end{array}$ & 60 menit & $\begin{array}{l}\text { Pemberian pertanyaan-pertanyaan reflektif untuk } \\
\text { menggali pengalaman belajar/pengalaman menguasai } \\
\text { sesuatu (experience of mastery) calon konselor yang } \\
\text { berkaitan dengan efikasi diri karier mereka, seperti: } \\
\text { a. Pengalaman unik apa yang telah Anda alami } \\
\text { selama berada di sekolah? } \\
\text { b. Bagaimana pendapat Anda mengenai profesi guru } \\
\text { BK yang akan Anda tekuni nanti? } \\
\text { c. Adakah pengalaman masa lalu Anda yang } \\
\text { nampaknya membuat Anda tidak yakin pada } \\
\text { profesi konselor? } \\
\text { d. Siapkah Anda untuk menyesuaikan diri di tempat } \\
\text { kerja Anda nanti? } \\
\text { e. Apakah Anda yakin bahwa Anda mampu untuk } \\
\text { menjadi guru BK/konselor yang profesional? }\end{array}$ \\
\hline Pertemuan 3 & $\begin{array}{l}\text { Pelaksanaan } \\
\text { tahap } \\
\text { Understand }\end{array}$ & 70 menit & $\begin{array}{l}\text { Materi yang disampaikan: } \\
\text { a. Pemantapan Keyakinan Diri Calon Konselor } \\
\text { terhadap Profesi yang Akan Ditekuni (mengacu } \\
\text { pada aspek experience of mastery). } \\
\text { b. Pemantapan Keyakinan Diri Calon Konselor untuk } \\
\text { Mencapai Keberhasilan (mengacu pada aspek } \\
\text { vicarious experience). }\end{array}$ \\
\hline \multirow[t]{2}{*}{ Pertemuan 4} & $\begin{array}{l}\text { Pelaksanaan } \\
\text { tahap } \\
\text { Understand }\end{array}$ & 70 menit & $\begin{array}{l}\text { Materi yang disampaikan: } \\
\text { a. Pemantapan Keyakinan Diri Calon Konselor untuk } \\
\text { Menumbuhkan Motivasi Diri (mengacu pada aspek } \\
\text { social persuation). }\end{array}$ \\
\hline & & & $\begin{array}{l}\text { b. Pemantapan Keyakinan Diri Calon Konselor } \\
\text { terhadap Kemampuan yang dimiliki (mengacu } \\
\text { pada aspek positive \& negative emotional state). }\end{array}$ \\
\hline \multirow[t]{6}{*}{ Pertemuan 5} & $\begin{array}{l}\text { Pelaksanaan } \\
\text { tahap Revise }\end{array}$ & 50 menit & $\begin{array}{l}\text { Pemberian pertanyaan-pertanyaan reflektif guna } \\
\text { mengetahui proses perbaikan atau revisi pemahaman } \\
\text { diri calon konselor yang dirasa kurang efektif menjadi } \\
\text { lebih efektif untuk produksi tingkah laku baru yang } \\
\text { lebih baik, seperti; }\end{array}$ \\
\hline & & & $\begin{array}{l}\text { a. Apakah Anda lebih yakin dengan kemampuan } \\
\text { yang Anda miliki saat ini? }\end{array}$ \\
\hline & & & b. Apakah Anda yakin untuk dapat berhasil nantinya? \\
\hline & & & $\begin{array}{l}\text { c. Bagaimana gambaran pemantapan keyakinan akan } \\
\text { keberhasilan Anda tersebut? }\end{array}$ \\
\hline & & & d. Apakah Anda mantap akan menjadi konselor? \\
\hline & & & $\begin{array}{l}\text { e. Apakah Anda akan patah semangat jika apa yang } \\
\text { Anda pilih nanti mengalami hambatan? }\end{array}$ \\
\hline Pertemuan 6 & $\begin{array}{l}\text { Pelaksanaan } \\
\text { tahap Use }\end{array}$ & 70 menit & $\begin{array}{l}\text { Praktik pemberian layanan informasi mengenai cara } \\
\text { belajar efektif }\end{array}$ \\
\hline Pertemuan 7 & $\begin{array}{l}\text { Pelaksanaan } \\
\text { tahap Use }\end{array}$ & 70 menit & Praktik pemberian layanan konseling individu \\
\hline Pertemuan 8 & $\begin{array}{l}\text { Pelaksanaan } \\
\text { tahap Use }\end{array}$ & 70 menit & $\begin{array}{l}\text { Praktik pemberian layanan bimbingan kelompok } \\
\text { mengenai rencana hidup ke depan }\end{array}$ \\
\hline Pertemuan 9 & Final Stage & 60 menit & Kesimpulan dan evaluasi serta pengisian Skala \\
\hline & & & $\begin{array}{l}\text { Pengukuran Efikasi Diri Karier oleh anggota kelompok } \\
\text { (posttest) }\end{array}$ \\
\hline
\end{tabular}


Mengacu pada pemaparan di atas, dilakukan penelitian yang bertujuan untuk menghasilkan media bimbingan dan konseling yang dapat diterima secara praktis dan teoretis. Media BK tersebut berupa paket pelatihan yang diberi nama paket pelatihan "GURU-Karier". Adapun rincian kegiatan dan jabaran materi pelatihan yang tercantum dalam paket pelatian ini dapat dilihat pada tabel 1.

Berdasarkan pemaparan tersebut serta untuk menguji keberterimaan paket pelatihan ini, maka dilakukan penelitian yang berjudul Pengembangan Paket Pelatihan "Ground, Understand, Revise, Use (GURU)-Karier” untuk Meningkatkan Efikasi Diri Karier Calon Konselor.

\section{METODE}

Pengembangan paket pelatihan "GURU-Karier" merujuk pada rancangan penelitian dan pengembangan Borg \& Gall (1983) yang secara keseluruhan terdapat 10 langkah. Namun, berdasarkan kondisi dan situasi dalam proses penyelesaian penelitian dan pengembangan ini, kesepuluh langkah penelitian dan pengembangan Borg \& Gall (1983) tersebut tidak dilaksanakan secara keseluruhan. Langkah penelitian dan pengembangan dalam pengembangan paket pelatihan "GURU-Karier" akan dilakukan sampai langkah ketujuh, yaitu: (1) research and informating collection; (2) planning; (3) develop preliminary form of product; (4) preliminary field testing; (5) main product revision; (6) main field testing; (7) operational product revision.

Subjek validasi ahli sebanyak 1 orang ahli BK dan 1 orang ahli pengembangan media pendidikan. Penetapan subjek uji ahli didasarkan pada beberapa pertimbangan atau dipilih secara purposive. Validasi ahli bidang BK pada pengembangan paket pelatihan ini didasarkan pada beberapa pertimbangan, yaitu: (1) memiliki latar belakang minimal S2 BK; (2) sebagai pengajar Prodi BK; (3) menguasai materi yang berkaitan dengan tujuan penelitian; dan (4) telah memiliki pengalaman mengajar minimal 3 tahun. Untuk validasi ahli pengembangan media pendidikan didasarkan pada beberapa pertimbangan, yaitu: (1) memiliki latar belakang minimal S2 TEP; (2) sebagai pengajar prodi TEP; (3) memiliki pemahaman mengenai pengembangan media BK; dan (4) telah memiliki pengalaman mengajar minimal 3 tahun.

Subjek uji pengguna sebanyak 1 orang dosen Prodi BK. Penetapan subjek dilakukan secara purposive, yaitu dengan kriteria: (1) telah menjadi dosen Prodi BK minimal 3 tahun; (2) pendidikan terakhir minimal S2 BK; (3) responsif terhadap pengembangan paket pelatihan ini. Subjek uji kelompok kecil berjumlah 6 orang mahasiswa S1 BK angkatan 2012 tahun ajaran 2015/2016 di Universitas Nusantara PGRI Kediri. Penetapan subjek dilakukan secara purposive, yaitu dengan kriteria: (1) mahasiswa S1 BK yang telah melaksanakan PPL 2/Magang di sekolah dan (2) memiliki efikasi diri karier yang rendah.

Instrumen penelitian yang digunakan yaitu: (1) kuesioner penilaian ahli; (2) pedoman observasi; (3) skala pengukuran efikasi diri karier; dan (4) pedoman wawacara. Analisis data angka yang diperoleh dari penilaian ahli (1 orang ahli BK dan 1 orang ahli pengembangan media pendidikan), uji pengguna (1 orang dosen BK) dan hasil observasi yaitu dengan mencari persentase dari hasil bagi skor hasil observasi dengan skor maksimal dan interval dari hasil penilaian ahli untuk menentukan rentang dari masing-masing kriteria. Adapun indikator kriteria keberterimaan/kelayakan untuk paket pelatihan "GURU-Karier" adalah: (1) kesesuaian dengan tujuan; (2) kesesuaian media dengan materi BK; (3) kesesuaian dengan karakteristik konseli; (4) kesesuaian dengan teori; (5) kesesuaian dengan gaya belajar konseli; (6) kesesuaian dengan kondisi lingkungan; (7) kemudahan akses; (8) efisiensi biaya; (9) kemudahan teknologi; (10) interaktivitas; (11) dukungan organisasi; dan (12) kebaruan media (Nursalim, 2013). Terdapat empat kriteria untuk interpretasi hasil penilaian yang dapat digunakan untuk mengambil keputusan bahwa paket pelatihan ini layak/dapat diterima sebagai media atau tidak, yaitu: (1) sangat baik dengan rentang 76\%-100\%; (2) baik dengan rentang $51 \%-75 \%$; (3) kurang baik dengan rentang $26 \%-50 \%$; dan (4) tidak baik dengan rentang $0 \%-25 \%$. 
Tabel 2. Hasil Uji Coba Paket Pelatihan "GURU-Karier"

\begin{tabular}{|c|c|c|}
\hline Uji Coba & Hasil & Interpretasi Hasil \\
\hline Uji Ahli BK & $\begin{array}{l}\text { Berdasarkan perhitungan skor penilaian ahli } \\
\text { diperoleh presentase sebesar 66\%. Paket } \\
\text { pelatihan telah direvisi sesuai masukan ahli BK } \\
\text { antara lain telaah ulang mengenai dukungan } \\
\text { lembaga dan peninjauan ulang langkah-langkah } \\
\text { praktik simulasi. }\end{array}$ & $\begin{array}{l}\text { Berdasarkan hasil penilaian tersebut, paket } \\
\text { pelatihan memasuki rentang kriteria Baik. } \\
\text { Dapat disimpulkan bahwa paket pelatihan } \\
\text { ini secara teoretis/ isi dapat digunakan } \\
\text { sebagai media untuk meningkatkan efikasi } \\
\text { diri karier calon konselor setelah melalui } \\
\text { proses revisi. }\end{array}$ \\
\hline Uji Ahli & Berdasarkan perhitungan skor penilaian ahli & Persentase hasil penilaian ahli \\
\hline Pengembangan & diperoleh presentase sebesar $93 \%$. Paket & pengembangan media pendidikan \\
\hline Media Pendidikan & $\begin{array}{l}\text { pelatihan telah direvisi sesuai masukan ahli } \\
\text { pengembangan media pendidikan yaitu } \\
\text { himbauan untuk mengoptimalkan aspek } \\
\text { visualnya. }\end{array}$ & $\begin{array}{l}\text { memasuki rentang kriteria Sangat Baik. } \\
\text { Jadi, secara visual tampilan paket pelatihan } \\
\text { ini dinilai dapat memenuhi kriterianya. }\end{array}$ \\
\hline Uji Pengguna & $\begin{array}{l}\text { Berdasarkan perhitungan skor penilaian } \\
\text { pengguna yaitu dosen BK UN PGRI Kediri } \\
\text { diperoleh presentase penilaian sebesar } 77 \% \text {. } \\
\text { Paket pelatihan telah direvisi sesuai masukan } \\
\text { pengguna yaitu himbauan untuk telaah ulang } \\
\text { perlu atau tidak simulasi konseling individu. }\end{array}$ & $\begin{array}{l}\text { Berdasarkan hasil penilaian tersebut, paket } \\
\text { pelatihan memasuki rentang kriteria Sangat } \\
\text { Baik. Dapat disimpulkan bahwa paket } \\
\text { pelatihan ini dapat digunakan sebagai } \\
\text { sarana dalam meningkatkan efikasi diri } \\
\text { karier calon konselor. }\end{array}$ \\
\hline $\begin{array}{l}\text { Uji Kelompok } \\
\text { Kecil }\end{array}$ & $\begin{array}{l}\text { Berdasarkan hasil uji Wilcoxon diperoleh } \\
\text { signifikasi sebesar 0,028. Dimana signifikansi } \\
\text { tersebut lebih kecil dari 0,05. Dapat } \\
\text { disimpulkan bahwa } \mathrm{H}_{0} \text { ditolak dan } \mathrm{H}_{1} \\
\text { diterima. }\end{array}$ & $\begin{array}{l}\text { Paket Pelatihan "GURU-Karier" terbukti } \\
\text { ampuh untuk meningkatkan efikasi diri } \\
\text { karier calon konselor. }\end{array}$ \\
\hline Kesimpulan & \multicolumn{2}{|c|}{$\begin{array}{l}\text { Mengacu pada hasil-hasil penilaian ahli dan uji kelompok kecil, dapat ditarik makna bahwa } \\
\text { paket pelatihan "GURU-Karier" dapat diterima baik secara teoretis dan praktis sebagai media } \\
\text { untuk meningkatkan efikasi karier calon konselor. }\end{array}$} \\
\hline
\end{tabular}

Sedangkan kriteria untuk menentukan tingkat efikasi diri karier calon konselor, yaitu: (1) Sangat Tinggi dengan rentang 59-72; (2) Tinggi dengan rentang 45-58; (3) Rendah dengan rentang 32-44; dan (4) Sangat Rendah dengan rentang 18-31. Untuk pengujian hipotesis dilakukan uji beda terhadap skor perolehan pretest dan posttest menggunakan Wilcoxon Signed Ranks Test. Pengujian ini menggunakan ketentuan sebagai berikut: (1) apabila signifikansi $>0,05$ maka $\mathrm{H}_{\mathrm{o}}$ diterima dan (2) apabila signifikansi $<0,05$ maka $\mathrm{H}_{\mathrm{o}}$ ditolak. Untuk data-data yang bersifat non angka/verbal yaitu berupa pendapat, saran, kritik atau masukan dari para ahli, dosen Prodi BK dan mahasiswa akan dideskripsikan kemudian menarik kesimpulan dari deskripsi tersebut, sehingga memberi gambaran yang jelas terhadap aspek yang dinilai.

\section{HASIL}

Media bimbingan dan konseling yang dihasilkan berupa paket pelatihan bernama paket pelatihan "GURU-Karier". Paket pelatihan ini terdiri dari 2 eksemplar, yaitu (1) paket pelatihan untuk pegangan konselor dan (2) paket pelatihan untuk pegangan konseli. Paket ini dapat digunakan sebagai sarana/wadah pesan bimbingan dan konseling untuk meningkatkan efikasi diri karier calon konselor. Paket ini berukuran panjang 29,7 cm dan lebar $21 \mathrm{~cm}$ atau setara dengan ukuran kertas A4. Tebal paket kurang lebih sekitar $1 \mathrm{~cm}$. Hasil uji coba paket ini dapat dilihat pada tabel 2.

\section{PEMBAHASAN}

Berdasarkan temuan lapangan dapat diketahui bahwa paket pelatihan ini telah terbukti layak/ dapat diterima sebagai media BK untuk meningkatkan efikasi diri karier calon konselor. Paket pelatihan "GURU-Karier" ini digunakan sebagai pegangan konselor yang minimal telah lulus S1 BK atau Dosen/Pengajar Program Studi Bimbingan dan Konseling minimal lulusan S2 BK agar dapat mengembangkan dan meningkatkan efikasi diri karier calon konselor atau mahasiswa S1 
BK sehingga calon konselor ini dapat menjadi konselor yang profesional ketika mereka bekerja baik di dalam sekolah maupun di luar sekolah.

Rendahnya efikasi karier pada calon konselor ini sangat perlu untuk ditingkatkan agar problematik bimbingan dan konseling yang terjadi di lapangan dapat tereduksi. Dapat diketahui bahwa problematik yang terjadi bukan hanya karena sistem pendidikan yang ada di Negara ini, namun sebagian besar juga berasal dari individu konselor itu sendiri. Konselor yang mempunyai efikasi diri yang tinggi akan lebih berkomitmen dengan profesi BK yang telah dipilih tersebut. Pernyataan ini senada dengan pendapat Gushu dkk (2006) yang menyatakan bahwa dengan adanya efikasi diri dalam pengambilan keputusan karier seberapa tinggi keyakinan individu dalam menyelesaikan suatu tugas, menentukan pilihan karier dan berkomitmen untuk pilihannya tersebut dapat ditunjukkan.

Bandura (1993; 1997) dalam Brusokas \& Malinauskas (2014) secara spesifik mengungkapkan fungsi efikasi diri karier yaitu seseorang yang memiliki efikasi diri karier yang tinggi cenderung lebih menetapkan tujuan karier yang lebih tinggi pula dan lebih tekun dalam mencapai tujuannya tersebut. Dapat dimaknai bahwa konselor yang mempunyai efikasi diri karier tinggi cenderung akan menetapkan tujuan karier yang lebih tinggi pula. Sehingga bagaimanapun kondisi tempat mereka bekerja maupun perubahan sistem pendidikan yang terjadi tidak akan membuat mereka hilang kendali dan pada akhirnya tidak dapat beradaptasi dengan kondisi yang ada. Apabila konselor sudah tidak mampu lagi survive dengan keadaan yang ada, dikhawatirkan profesi BK juga semakin lama akan semakin tenggelam. Oleh karena itu sangat penting dilakukan pelatihan efikasi diri karier kepada calon konselor, khususnya menggunakan media berupa paket pelatihan "GURUKarier" tersebut.

Penggunaan media dalam pemberian layanan BK merupakan hal yang sangat dianjurkan. Elfarini \& Christiana (2013) mengutarakan bahwa dengan menggunakan media bimbingan dan konseling, siswa akan banyak melibatkan indera (penglihatan, pendengaran, peraba, perasa, penciuman) yang pada akhirnya dapat mencapai hasil yang sesuai dengan tujuan bimbingan secara maksimal. Penggunaan media secara kreatif akan memperbesar kemungkinan bagi siswa tertarik pada layanan bimbingan dan konseling serta untuk belajar lebih banyak, mencamkan apa yang dipelajarinya lebih baik dan meningkatkan penampilan dalam melakukan keterampilan sesuai dengan yang menjadi tujuan bimbingan dan konseling (Nursalim, 2013). Media juga berfungsi sebagai wadah pesan bimbingan itu sendiri. Sebuah teknik bimbingan akan lebih jelas dan operasional jika diwadahi dengan media.

Telah dijelaskan sebelumnya bahwa faktor yang paling berpengaruh pada efikasi diri karier adalah pengalaman individu itu sendiri. Teknik yang dipilih adalah proses GURU dimana komponen yang paling diutamakan dalam teknik ini juga pengalaman seseorang dalam menguasai sesuatu. Selain itu proses GURU dinilai luwes untuk dikolaborasikan dengan bentuk media apapun. Keunggulan lain dari proses GURU adalah: (1) individu dapat mempertimbangkan dan menentukan tindakan apa yang akan dilakukan untuk merespon situasi yang sedang dialami; (2) mengontrol tingkat emosi; (3) mempercepat proses adaptasi dengan lingkungan baru; (4) mengubah arah pikir konseli, yang semula mempunyai pola pikir yang kurang/tidak efektif menjadi pola pikir yang lebih efektif; (5) lebih cermat dalam mempertimbangkan informasi; (6) dapat mengevaluasi kinerja/ tindakan yang telah dilakukan atau dapat menentukan keefektifan dari tindakan tersebut; dan (7) dapat merencanakan tindakan apa saja yang perlu dilakukan untuk situasi selanjutnya (Remer, 2007). Maka, paket pelatihan "GURU-Karier" terpilih menjadi media untuk mengakomodasi halhal tersebut.

Berdasarkan hasil uji coba lapangan, paket pelatihan "GURU-Karier" dapat diterima baik secara teoretis dan praktis sebagai media untuk meningkatkan efikasi diri karier calon konselor. Paket pelatihan yang telah teruji dan layak untuk digunakan ini terdiri dari 2 eksemplar, yaitu (1) paket pelatihan untuk pegangan konselor dan (2) paket pelatihan untuk pegangan konseli. Paket pelatihan ini telah memenuhi kriteria keberterimaan/kelayakan yaitu: (1) kesesuaian dengan tujuan; (2) kesesuaian media dengan materi BK; (3) kesesuaian dengan karakteristik konseli; (4) kesesuaian dengan teori; (5) kesesuaian dengan gaya belajar konseli; (6) kesesuaian dengan kondisi lingkungan; 
(7) kemudahan akses; (8) efisiensi biaya; (9) kemudahan teknologi; (10) interaktivitas; (11) dukungan organisasi; dan (12) kebaruan media.

Keberhasilan dalam pelaksanaan pelatihan efikasi diri karier calon konselor ini tidak hanya ditentukan oleh kualitas paket pelatihan "GURU-Karier", tetapi juga tidak terlepas dari beberapa faktor penunjang seperti kondisi dan situasi konseli saat pelaksanaan pelatihan serta kondisi konselor sebagai pemimpin kelompok. Seperti yang dijelaskan sebelumnya, bimbingan dan konseling merupakan suatu sistem. Untuk tercapainya suatu tujuan bimbingan dan konseling tentunya dipengaruhi oleh masing-masing komponen yang ada dalam sistem dan media hanya merupakan salah satu komponen dari sistem tersebut.

\section{SIMPULAN}

Berdasarkan hasil penelitian dan pengembangan ini, telah dihasilkan sebuah media BK berupa Paket Pelatihan "GURU-Karier" yang dapat diterima secara teoretis dan praktis. Paket pelatihan ini telah memenuhi kriteria keberterimaan/kelayakan yaitu: (1) kesesuaian dengan tujuan; (2) kesesuaian media dengan materi BK; (3) kesesuaian dengan karakteristik konseli; (4) kesesuaian dengan teori; (5) kesesuaian dengan gaya belajar konseli; (6) kesesuaian dengan kondisi lingkungan; (7) kemudahan akses; (8) efisiensi biaya; (9) kemudahan teknologi; (10) interaktivitas; (11) dukungan organisasi; dan (12) kebaruan media. Paket pelatihan yang telah teruji dan layak untuk digunakan ini terdiri dari 2 eksemplar, yaitu (1) paket pelatihan untuk pegangan konselor dan (2) paket pelatihan untuk pegangan konseli.

Saran ditujukan kepada Guru BK/konselor dan para dosen BK dapat menggunakan paket pelatihan "GURU-Karier" untuk meningkatkan efikasi diri karier calon konselor. Selain itu Guru BK/konselor dan para dosen BK dapat menggunakan paket pelatihan ini sebagai sarana pengembangan pribadi konselor. Saran selanjutnya bagi peneliti yang berminat untuk melakukan penelitian lanjutan dapat menggunakan subjek penelitian yang lebih luas. Serta mengganti rancangan penelitian menggunakan rancangan penelitian eksperimental dengan kelompok kontrol atau rancangan penelitian tindakan bimbingan dan konseling (PTBK).

\section{DAFTAR PUSTAKA}

Anisa, S. \& Nursalim, M. 2010. Efektifitas Media "Pizza Karier" dalam Pemberian Layanan Informasi Karier. Jurnal Unesa, hlm 1-13, (Online), (http://ppb.jurnal.unesa.ac.id), diakses 28 Nopember 2012.

Bandura, A. 1993. Perceived Self-Efficacy in Cognitive Development and Functioning. Educational Phychologist, Vol. 28 (2): 117-148.

Bandura, A. 1994. Self Efficacy. Encyclopedia of Human Behavior, Vol. 4: 71-81.

Bandura, A. 1998. Personal and Collective Efficacy in Human Adaptation and Change. Hove, UK: Psychology Press.

Bandura, A., Barbaranelli, C., Caprara, G.V., \& Pastorelli, C. 2001. Self-Efficacy Beliefs as Shapers of Children's Aspirations and Career Trajectories. Child Development, Vol. 72 (1): 187206.

Bandura, A. 2009. Self Efficacy in Changing Societies. New York: Cambridge University Press.

Betz, N.E. 2007. Career Self-Efficacy: Exemplary Recent Research and Emerging Directions. Journal of Career Assessment, Vol. 15 (4): 403-422.

Borg, W.R. \& Gall, M.D. 1983. Educational Research. An Introduction. White Plain, New York: Longman, Inc.

Bozgeyikli, H., Eroglu, S.E., \& Hamurcu, H. 2009. Career Decision Making Self-Efficacy, Career Maturity And Socioeconomic Status With Turkish Youth. Georgian Electronic Scientific Journal: Education Science and Psychology, Vol. 1 (14): 15-24.

Brown, N.W. 2004. Psychoeducational Groups: Process and Practice. New York: BrunnerRoutledge. 
Brusokas, A. \& Malinauskas, R. 2014. Career Self-Efficacy Among Lithuanian Adolescents in Sports Schools. Procedia - Social and Behavioral Sciences, No. 116: 212-216.

Corey, M.; Corey, G; dan. Corey, C. 2014. Groups: Process and practice. $9^{\text {th }}$ Ed. Belmont, CA: Brooks/Cole.

DeLucia-Waack, J.L. 2006. Leading Psychoeducational Groups. California: Sage Publications, Inc.

Elfarini, R.S. \& Christiana, E. 2013. Pengembangan Media Monopoli Asertif untuk Meningkatkan Pemahaman Siswa Tentang Perilaku Asertif pada Siswa Kelas VIII-A. Jurnal Bimbingan Konseling, Vol. 1 (1): 174-185.

Feehan, P.F. \& Johnston, J.A. 1999. The Self-Directed Search and Career Self-Efficacy. Journal of Career Assessment, Vol. 7 (2): 145-159.

Gibson, R.L. \& Mitchell, M.H. 2008. Bimbingan dan Konseling. Terjemahan Yudi Santoso. 2011. Yogyakarta: Pustaka Pelajar.

Gushu, G.V., Scanlan, K.R.L., Pantzer, K.M., \& Clarke, C.P. 2006. The Relationship of Career Decision-Making Self-Efficacy, Vocational Identity, and Career Exploration Behavior in African American High School Students. Journal of Career Development, Vol. 33 (1): $19-28$.

Hanggara, G.S. 2016. Keefektifan "Proses Guru" sebagai Teknik Bimbingan Kelompok dalam Meningkatkan Pengambilan Keputusan Karier Siswa SMK. Tesis. Malang: Program Pasca Sarjana. Universitas Negeri Malang. Jurusan Bimbingan dan Konseling.

Leksana, D.M., Wibowo, M.E., \& Tadjri, I. 2013. Pengembangan Modul Bimbingan Karir Berbasis Multimedia Interaktif untuk Meningkatkan Kematangan Karir Siswa. Jurnal Bimbingan Konseling, Vol. 2 (1): 1-9.

Nursalim, M. 2013. Pengembangan Media Bimbingan dan Konseling. Jakarta: PT Indeks.

Prayitno \& Amti, E. 2009. Dasar-dasar Bimbingan dan Konseling. Jakarta: PT Rineka Cipta.

Remer, B. 2007. Reflective Practice: Learning from Real-World Experience. Dalam Silberman, M, (ed). The Handbook of Experiential Learning. San Fransisco: John Wiley \& Sons. Inc.

Santoso, D.B. 2011. Dasar-Dasar Bimbingan dan Konseling. Malang: Fakultas Ilmu Pendidikan Universitas Negeri Malang.

Schunk, D.H. 1991. Self Efficacy and Academic Motivation. Educational Psychologist, Vol. 26 (3 \& 4): 207-231.

Setyaputri, N.Y., Ramli, M., \& Mappiare-AT, A. 2015. Pengembangan Media Permainan "Roda Pelangi" untuk Meningkatkan Efikasi Diri Siswa SMP dalam Menghadapi Ujian. Bimbingan dan Konseling, Vol. 28 (1): 38-46.

Silberman, M. 2007. The Handbook of Experiential Learning. San Fransisco: John Wiley \& Sons. Inc. 